\title{
Experiments to Validate the NRCC Smoke Movement Model for Fire Risk-Cost Assessment
}

\author{
AKIHIKO HOKUGO \\ Building Research Institute \\ Ministry of Construction \\ Tatehara 1, Tsukuba-City 305, Japan \\ DAVID YUNG and GEORGE V. HADJISOPHOCLEOUS \\ National Fire Laboratory \\ Institute for Research in Construction \\ National Research Council of Canada \\ Ottawa, Ontario K1A 0R6, Canada
}

\begin{abstract}
The smoke movement model developed at the National Research Council of Canada (NRCC) as part of its risk-cost assessment model is a simple computer model for calculating the probabilities of smoke hazard in multi-storey buildings. To validate this model, full-scale smoke movement experiments were conducted at the 10-storey experimental smoke tower at the National Fire Laboratory of the NRCC. The 10-storey tower was designed and built to study smoke movements in highrise buildings. Results of the experiments show good agreement between the data and the simple smoke movement model.
\end{abstract}

KEYWORDS: smoke movement; multi-storey building; full-scale experiment; risk-cost assessment

\section{INTRODUCTION}

There is a trend in many countries of the world, notably U.K. and New Zealand, to move towards performance-based building codes. This trend is a welcome sign to building designers and owners because performance-based codes permit freedom in design which often leads to innovative designs that are equivalent in life safety performance but lower in construction costs. The trend towards performance-based codes is triggered by recent advances in computer fire modelling which permit rational assessment of fire safety performance in buildings. In Japan, a five-year research project (1993-1997) is being conducted by the Building Research Institute ( BRI ) of the Ministry of Construction with the objective to develop comprehensive fire safety assessment methods for performance-based regulations. In Canada, the National Building Code of Canada plans to introduce performance-based requirements by the year 2000 and at the National Research Council of Canada (NRCC), a risk-cost assessment model is being developed as a tool to support the introduction of such performance-based requirements. 
The NRCC risk-cost assessment model [1] is a computer model that can evaluate the life risks and fire costs in a building, as a result of all probable fire scenarios that may occur in the building over the lifetime of the building. The model evaluates the risks and costs by assessing the dynamic interaction between fire growth, fire and smoke spread, detection and suppression systems and human response. One of the submodels that has been developed as part of this risk-cost assessment model is a simple, one-zone smoke movement model [2]. Compared with other more sophisticated smoke movement models, this one-zone smoke movement model is much faster in computation time. In addition, the smoke movement model can assess smoke spread to a large number of compartments in a typical highrise building. The NRCC smoke movement model, therefore, is designed for risk assessment of smoke spread in highrise buildings where a large number of smoke spread scenarios must be considered.

The present paper describes experiments that have been conducted to validate the NRCC smoke movement model. The work was carried out with the financial support of an NRCC one-year fellowship, given to the first author from BRI, as a means to foster closer collaboration between BRI and NRCC in risk assessment in the future.

\section{THE NRCC SMOKE MOVEMENT MODEL}

As mentioned earlier, the smoke movement model [2] was developed as a submodel of the NRCC risk-cost assessment model. In the NRCC risk-cost assessment model, the development of a fire in the compartment of fire origin is modelled by a one-zone fire growth model [3]. The smoke movement model takes the output from the fire growth model and calculates the spread of smoke in the building, yielding the temperature and concentration of toxic gases at every location in the building as a function of time. Included in the model predictions are mass flowrates and pressure at every location in the building.

Details of the model are given in Reference 2. The model assumes that each location in a building, such as an apartment or a corridor, is one cell and calculates the development of concentrations of toxic gases and temperature in each cell based on the flowrates of mass and energy into and out of that cell. The flowrate through an opening, such as a doorway, into a cell is governed by pressure differences due to both buoyancy effect, as a result of the high temperature of the hot gases, and to stack effect, as a result of the temperature difference between the inside and outside of the building. Input data required include: (1) the layout of the building which includes the size of the door openings; (2) the mass flowrate of the hot gases leaving the compartment of fire origin, their concentrations and temperature; and (3) indoor temperature before the fire starts and outdoor air temperatures. Output from the model include: (1) the concentrations and temperature of toxic gases at every location in the building as a function of time; and (2) the probability of smoke hazard in each location based on the development of concentrations and temperature of toxic gases. In this study, only the predicted concentrations and temperature are compared with the experimental data.

The model's limitations and assumptions are as follows:

1. each location in the building is considered as one cell with uniform concentrations, temperature and pressure;

2. two zones are considered in the corridor on the floor of fire origin; 
3. the hot gases from the corridor enter through doors to other compartments on the floor of fire origin and to the stairshaft;

4. the heat losses to the walls of the corridor are not calculated; to account for the heat losses, the empirical relation given by Evers and Waterhouse [4] is used;

5. the force driving the hot gases from the corridor to the stairshaft is buoyancy coupled with stack effect;

6. the effects of wind and HVAC systems are neglected;

7. the volume of the stairshaft above the floor of fire origin is assumed to be one cell, hence, the gases entering the stairshaft mix instantly with the air in the stairshaft occupying this volume;

8. buoyancy forces cause the toxic gases in the stairshaft to move through openings from the stairshaft to the upper floors;

9. the gases entering the upper floors are assumed to mix instantly with the air in the corridors on these floors;

10. the hot gases in the corridors on the upper floors move into the compartments connected to them.

11. toxic gases entering a particular compartment mix instantly with the air in that compartment.

\section{EXPERIMENT}

Experiments were planned, using the NRCC 10-storey experimental smoke spread tower, to check the validity of the smoke movement model. The 10 -storey tower was fitted to simulate a 10-storey apartment building with apartments, corridors, stair and elevator shafts. The exterior walls and the walls of the internal shafts are fitted with variable openings that can

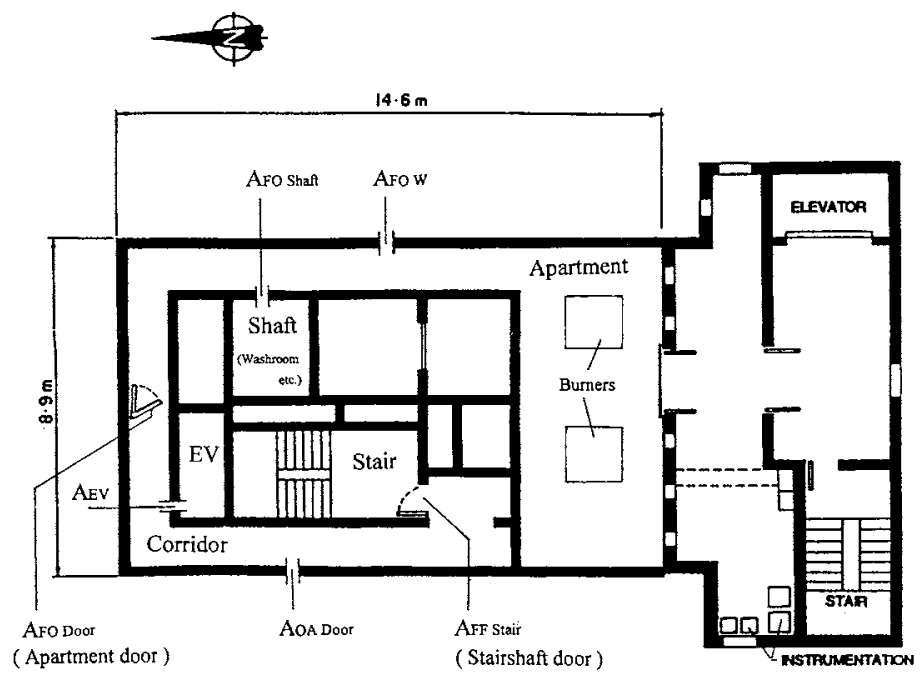

FIGURE 1. Layout of the fire floor ( second floor) of the 10-storey tower. 
be set to simulate the leakage area of a typical apartment building. Figure 1 shows the floor plan of the 10-storey tower. Two propane gas burners, each capable of producing a heat release rate of $2.5 \mathrm{MW}$, are located in the burn area on the second floor. Fresh air for the burners was piped in from the outside.

\section{TABLE 1. Test conditions.}

\begin{tabular}{|c|c|c|c|c|c|c|c|c|c|c|c|}
\hline No. & $\begin{array}{l}\text { Fire } \\
{ }^{\circ} \mathrm{C}\end{array}$ & $\begin{array}{l}\text { Afo } w \\
m^{2}\end{array}$ & $\begin{array}{l}\text { Afo Shaft } \\
\mathrm{m}^{2}\end{array}$ & Afo Daor & $\begin{array}{l}\text { AoA Door } \\
\mathrm{m}^{2}\end{array}$ & AfF Stair & AOF Stair & $\begin{array}{l}\text { Aof Door } \\
\mathrm{m}^{2}\end{array}$ & $\begin{array}{l}\text { Aof w } \\
\mathrm{m}^{2}\end{array}$ & $\begin{array}{l}\text { Aof Shaft } \\
\mathrm{m}^{2}\end{array}$ & $\begin{array}{l}\mathrm{AEV} \\
\mathrm{m}^{2}\end{array}$ \\
\hline 1 & 650 & 0.04 & 0.0024 & Open & 0.02 & Open & $1 / 10$ & 0.02 & 0.08 & 0.024 & 0.05 \\
\hline 2 & 650 & 0.04 & 0.0024 & Open & 0.02 & Closed & Closed & 0.02 & 0.08 & 0.024 & 0.05 \\
\hline 3 & 650 & 0.04 & 0.0024 & Closed & 0.02 & Open & $1 / 10$ & 0.02 & 0.08 & 0.024 & 0.05 \\
\hline 4 & 650 & 0.04 & 0.0024 & Closed & 0.02 & Closed & Closed & 0.02 & 0.08 & 0.024 & 0.05 \\
\hline 5 & 460 & 0.04 & 0.0024 & Open & 0.02 & Open & $1 / 10$ & 0.02 & 0.08 & 0.024 & 0.05 \\
\hline 6 & 460 & 0.04 & 0.0024 & Open & 0.02 & Closed & Closed & 0.02 & 0.08 & 0.024 & 0.05 \\
\hline 7 & 320 & 0.04 & 0.0024 & Closed & 0.02 & Open & $1 / 10$ & 0.02 & 0.08 & 0.024 & 0.05 \\
\hline 8 & 320 & 0.04 & 0.0024 & Closed & 0.02 & Closed & Closed & 0.02 & 0.08 & 0.024 & 0.05 \\
\hline
\end{tabular}

Notes: 1. See Figs. 1 and 2 for locations of openings.

2. $1 / 10=$ one tenth of the door is open.

3. All doors on first floor are closed.

4. AOA Door and $\operatorname{AEv}$ (2nd floor) are slot openings.

Table 1 lists the 8 experimental conditions which include 3 different fires, two positions of the door of the apartment of fire origin (AFo Door), two positions of the stairshaft door on the fire floor (AFr Stair), and two positions of the stairshaft door on the other floors (Aor Stair). Figure 2 shows the floor layouts of the experimental tower which were fitted to simulate the typical floor layouts of an apartment building. The various sizes of window openings and leakage areas shown in Table 1 were determined using the following:

$\begin{array}{ll}\text { AFO } & =0.04 \mathrm{~m}^{2} \text { (window assumed partly broken) } \\ \text { AOF } \mathrm{w} & =0.08 \mathrm{~m}^{2} \text { (assumed combined leakage area of } 10 \text { apartment units) } \\ \text { AFO Shaft } & =0.0024 \mathrm{~m}^{2} \text { (assumed leakage area with pipe penetrations) } \\ \text { AOF Shaft } & =0.024 \mathrm{~m}^{2} \text { (assumed combined leakage area of } 10 \text { apartment units) } \\ \text { AOA Door } & =0.02 \mathrm{~m}^{2} \text { (assumed combined opening of } 10 \text { apartment units [5]) } \\ \text { AoF Door } & =0.02 \mathrm{~m}^{2} \text { (assumed combined opening of } 10 \text { apartment units [5]) } \\ \text { AEV } & =0.05 \mathrm{~m}^{2} \text { (assumed leakage area [6]) }\end{array}$

In the experiment, propane burners were used to simulate the fire. The temperature at the burner on the fire floor was controlled to follow the curves of three design fires: (1) flashover fire in an apartment with the door open or closed, (2) non-flashover fire with the door open, and (3) non-flashover fire with the door closed. These curves, shown in Figure 3, were obtained from the NRCC apartment fire growth model [3]. 

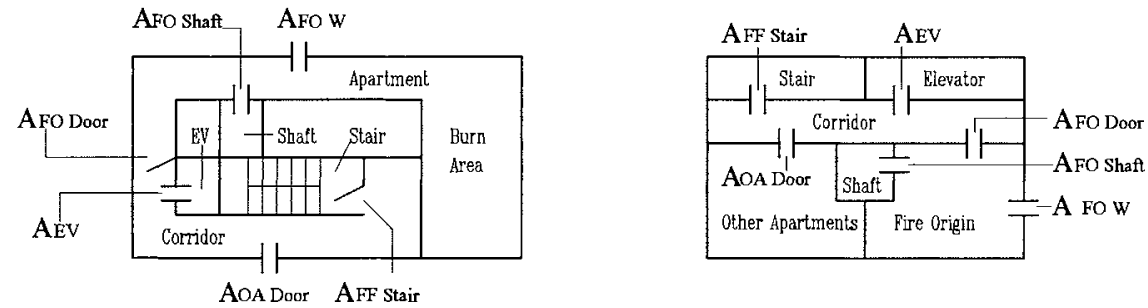

2nd Floor (Fire Origin)
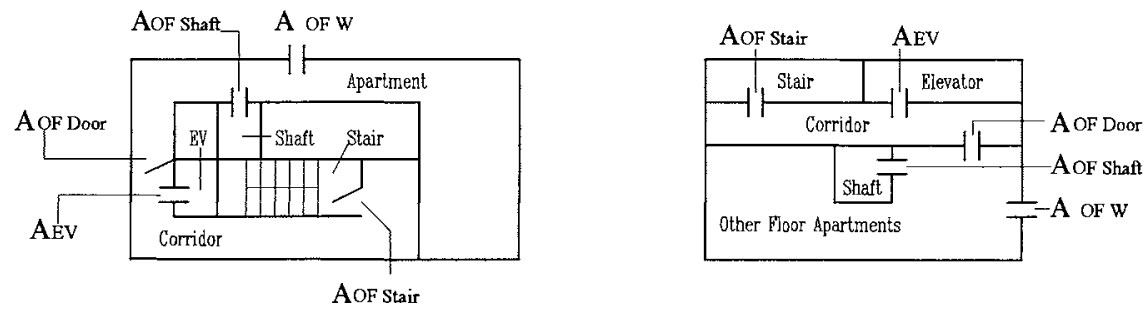

3rd-10th Floor (Other Floors)

FIGURE 2. The floors of the experimetal tower (left) were fitted to simulate the typical floor layouts of an apartment building (right).

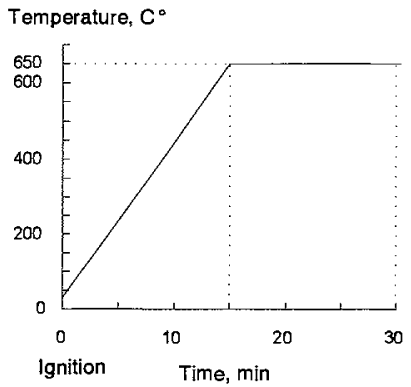

(a) Flashover fire with the door
open or closed

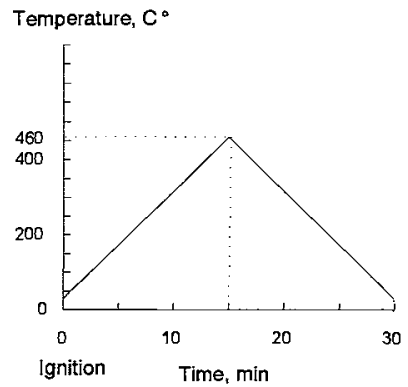
(b) Non-flashover flre with the door open

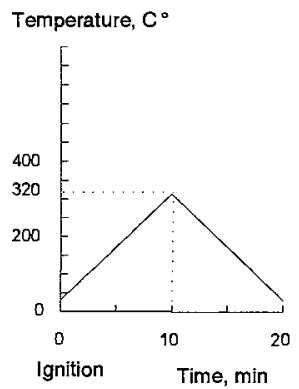

(c) Non-flashover fire with the door closed

FIGURE 3. Three different fire temperature profiles were used to represent three different types of fires. 
Temperatures were measured at three different locations on each floor: (1) at the apartment door (apartment side), (2) at the stairshaft door (corridor side) and (3) in the stairshaft. Pressure taps were used to measure the pressure differences across the apartment door, across the stairshaft door and between the corridor and the outside of the building. Carbon dioxide concentrations were measured at the same three locations on each floor where the temperatures were measured. The distribution of the velocity pressures with 5 probes and temperatures with 7 thermocouples were measured at the apartment door to calculate the flowrates of gases. To calculate the flowrates of gases, the method described in the SFPE Handbook [7] was used.

\section{MODEL PREDICTIONS}

The NRCC smoke movement model was used to predict the smoke spread in the 10storey experimental smoke spread tower which was fitted to simulate a typical 10-storey apartment building with 10 apartments on each floor. The predictions from the model and the experimental results were compared to check the validity of the model.

The 10-storey tower simulates an apartment building with each floor having a total floor area of $1300 \mathrm{~m}^{2}$, a stair and an elevator shaft in the center of the building, a corridor having a width of $1.5 \mathrm{~m}$ and a length of $14 \mathrm{~m}$ from one end of the building to the stairshaft (see Figure 2).

In the prediction of smoke spread, the measured temperatures, the $\mathrm{CO}_{2}$ concentration and the calculated flowrate of gases at the apartment door of the fire floor (second floor) were used as input data of the model. In the NRCC risk-cost assessment model, the input to the smoke movement model is normally provided by the output of the NRCC apartment fire growth model. In these tests, the actual measured values were used as input to the smoke movement model.

\section{RESULTS AND DISCUSSIONS}

Eight tests were planned, as shown in Table 1 . However, only Test No. 1 was completed at the present time. Test No.1 was conducted on September 2, 1993. Wind speed during the test was less than $5 \mathrm{~km} / \mathrm{h}$ and the atmospheric temperature was about $24^{\circ} \mathrm{C}$.

Figure 4 shows the temperature and velocity distribution at the apartment door during the test. The flow of hot gases is seen to be mainly in the upper half of the doorway. Figure 5 shows the calculated mass flow rates and measured $\mathrm{CO}_{2}$ concentrations at the apartment door.

Figure 6 shows the pressure differences across the apartment door, across the stairshaft door and between the corridor and the outside of the building. In the test, the pressure differences of the floors $4,5,7$ and 8 were not obtained. Figure 7 shows the measured and predicted temperatures on selected floors in the corridor and the stairshaft. Figure 8 shows the measured and predicted $\mathrm{CO}_{2}$ concentrations on selected floors in the corridor and the stairshaft. In the test, the $\mathrm{CO}_{2}$ concentrations of floors 4,6 and 7 were not obtained. 


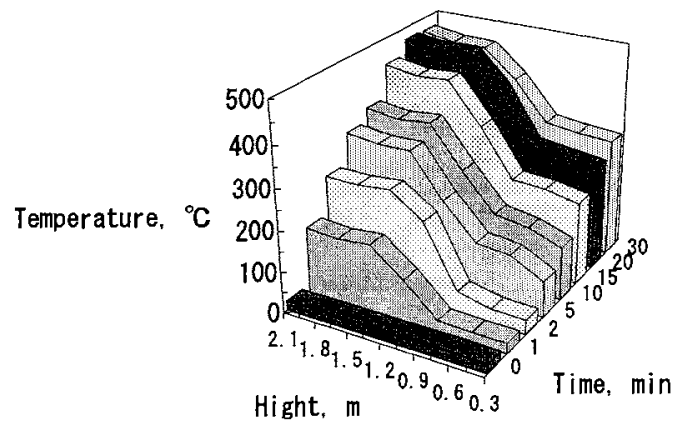

(a) Temperature, ${ }^{\circ} \mathrm{C}$

Velocity

- Pressure, Pascal

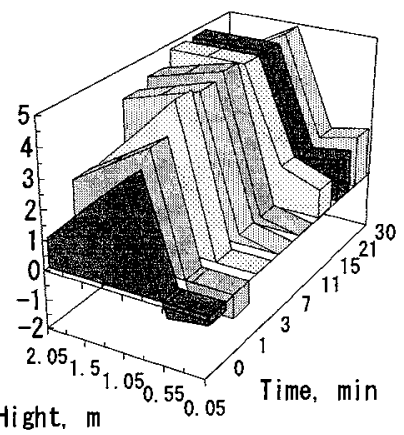

(b) Velocity Pressure, Pascal

FIGURE 4. Temperature and velocity distribution at the apartment door of the fire floor during the test No. 1.

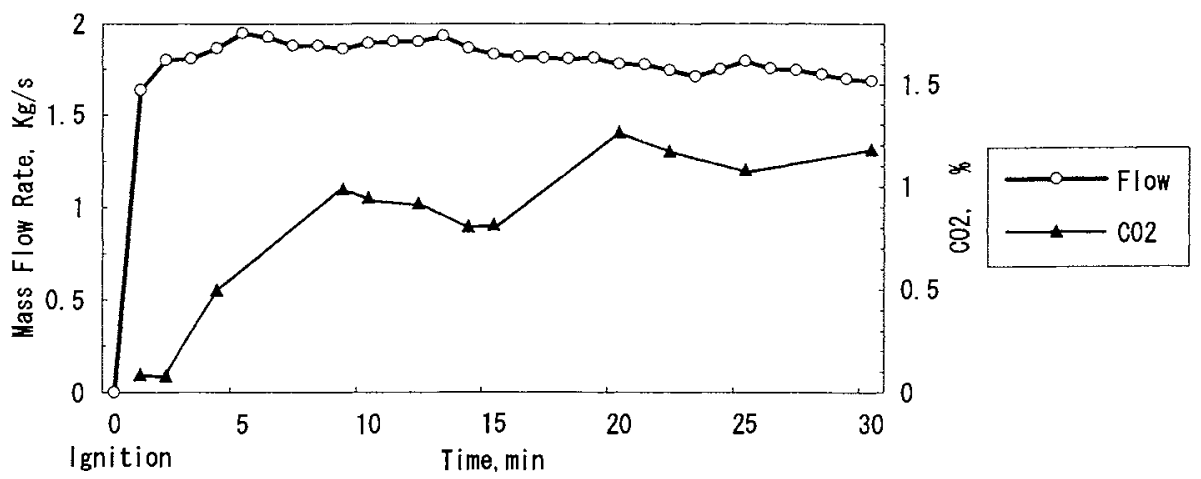

FIGURE 5. Mass flow rates and $\mathrm{CO} 2$ concentrations at the apartment door of the fire floor during the test No. 1 . 


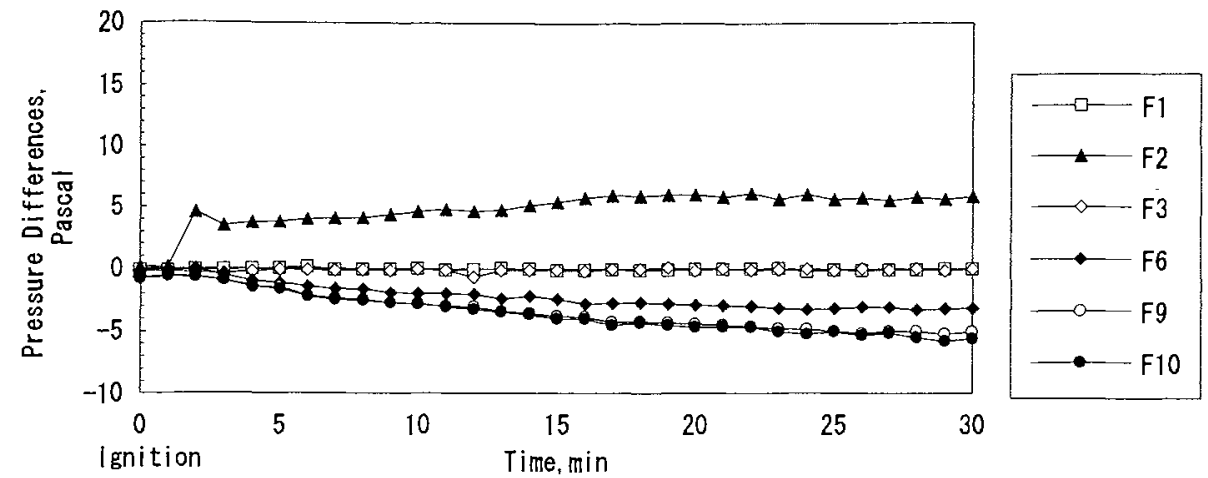

(a) Pressure differences across the apartment door
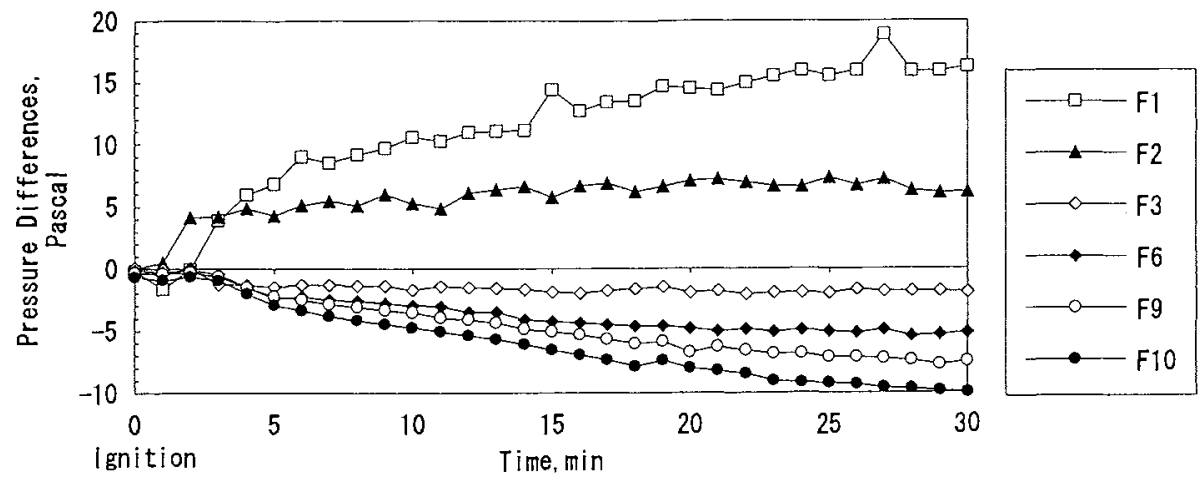

(b) Pressure differences across the stair door

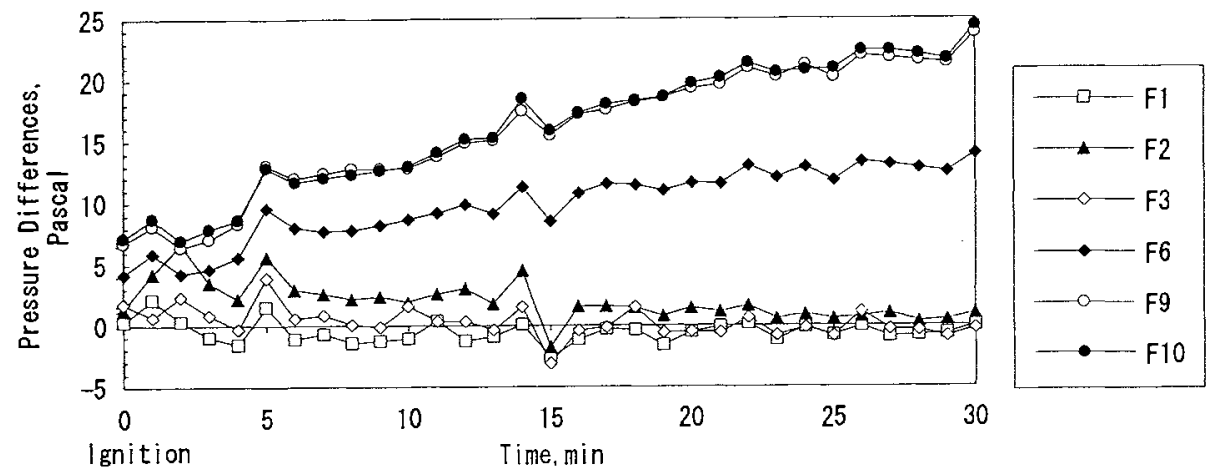

(c) Pressure differences between the corridor and the outside

FIGURE 6. Pressure differences during the test No. 1. 


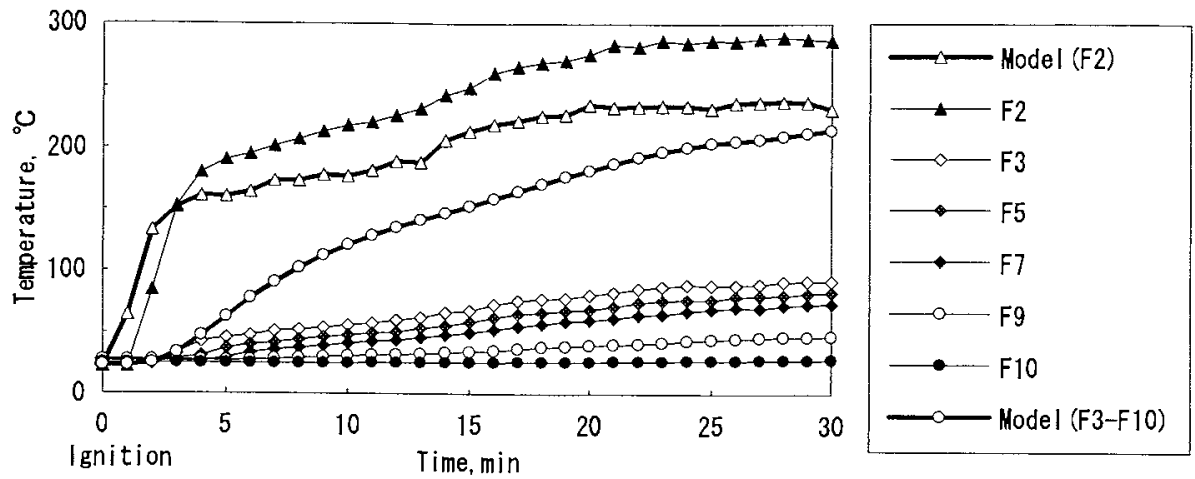

(a) Temperatures in the corridor

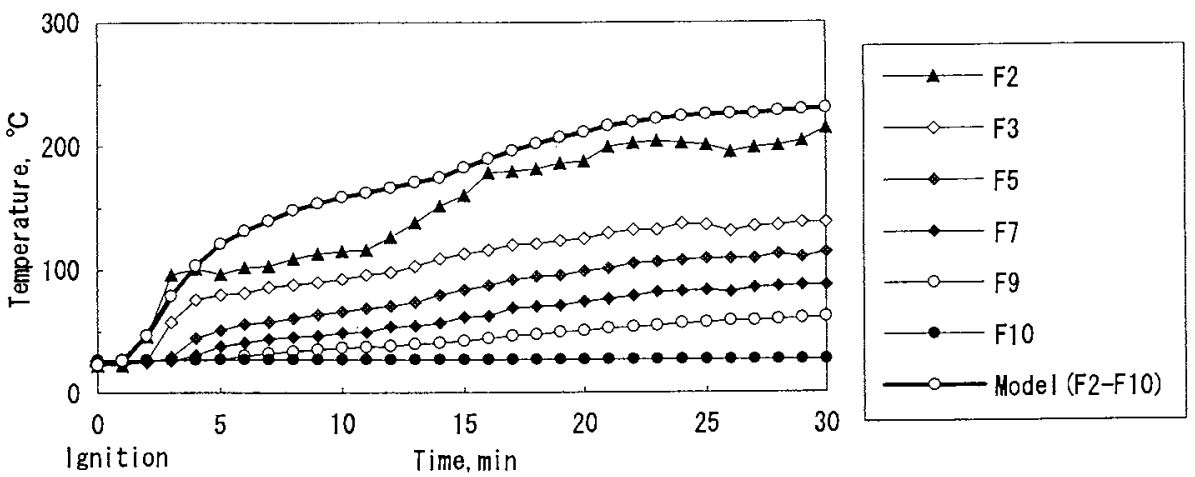

(b) Temperatures in the stairshaft

FIGURE 7. Measured and predicted temperatures during the test No. 1. 


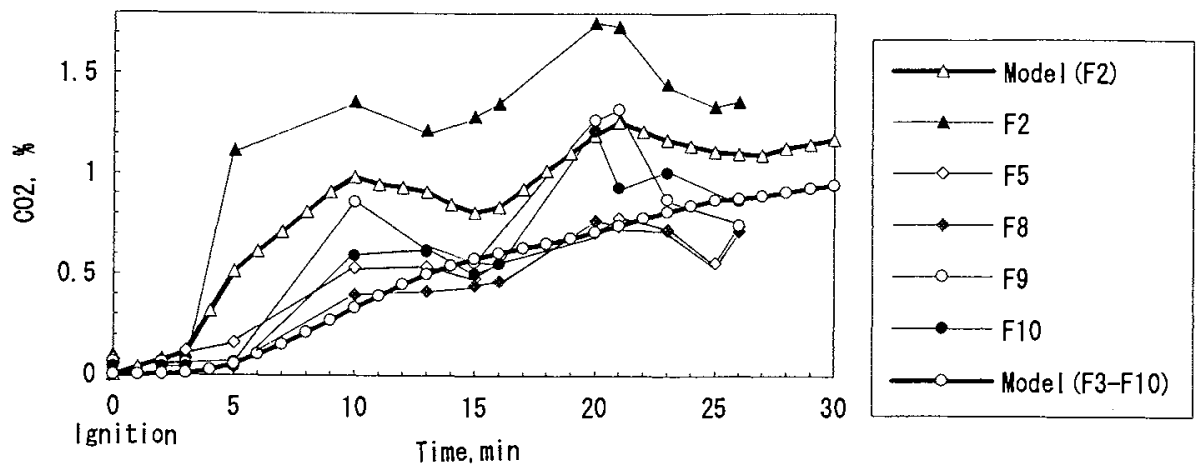

(a) $\mathrm{CO}_{2}$ concentrations in the corridor

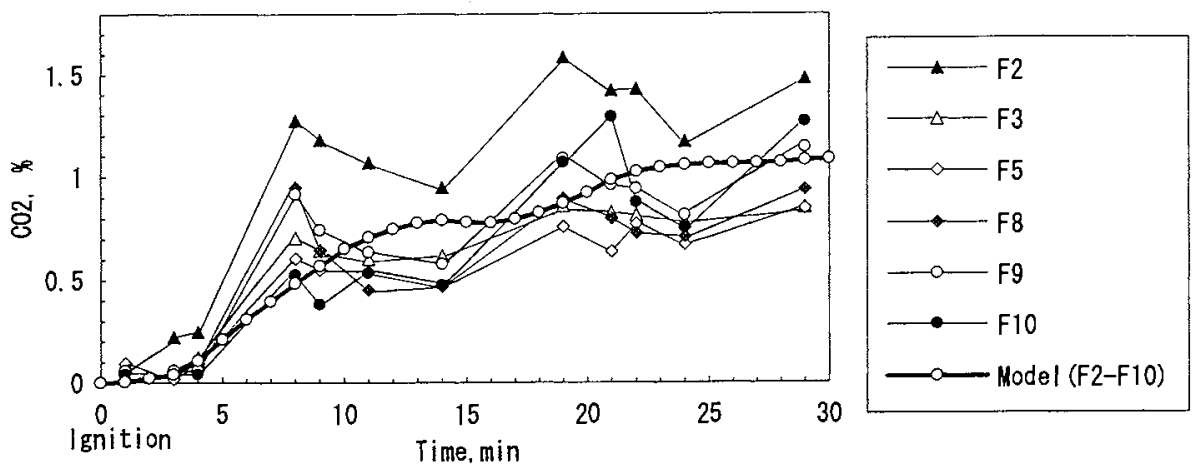

(b) $\mathrm{CO}_{2}$ concentrations in the stairshaft

FIGURE 8. Measured and predicted $\mathrm{CO}_{2}$ concentrations during the test No. 1. 
The results show good agreement between the model and the test, except for the temperatures in the corridors on the upper floors and the stairshaft. Figure 7 shows that the model overestimates the temperatures in the corridors in the upper floors and in the stairshaft. This over estimate could be the result that the model did not take into account heat losses to walls in the stairshaft and in the corridors except for the fire floor.

Figures 7 and 8 show that the model underestimates both the temperature and the $\mathrm{CO}_{2}$ concentrations in the corridor on the fire floor and, in addition, the $\mathrm{CO}_{2}$ concentration in the corridors on the upper floors. This could be the result that in the test, the values near the ceiling, where the hot layer was, were measured and in the model, the average values in the corridors were predicted.

\section{CONCLUSIONS}

In this study, predicted temperature values and $\mathrm{CO}_{2}$ concentrations using the NRCC smoke movement model were compared with measured data from full-scale fire test using the NRCC 10-storey smoke spread tower. The model was found to be in general agreement with the experiment.

Further tests are being planned using different fire scenarios. The results will be compared with the model and will be used to modify the model, if necessary, for better predictions.

\section{ACKNOWLEDGEMENTS}

The authors would like to thank Mr. George Tamura of the National Research Council of Canada (NRCC) for valuable comments and Mr. Don Carpenter, also of NRCC, for carrying out the experiments at the National Fire Laboratory. The first author (AH) would also like to thank the NRCC for the fellowship which enabled him to work at the NRCC for one year. Because of this initial work, further collaboration is expected between the Building Research Institute and the NRCC. 


\section{REFERENCES}

1. Yung, D., Hadjisophocleous, G.V. and Takeda, H., "Comparative Risk Assessments of 3Storey Wood-Frame and Masonry Construction Apartment Buildings", Proceedings of Interflam '93, Oxford, U.K., pp. 499-508, 1993.

2. Hadjisophocleous, G.V. and Yung, D., "A Model for Calculating the Probabilities of Smoke Hazard from Fires in Multi-Storey Buildings", J. of Fire Prot. Engr., Vol.4, No.2, pp.53-66, 1992.

3. Takeda, $H$. and Yung, D., "Simplified Fire Growth Models for Risk-Cost Assessment in Apartment Buildings", J. of Fire Prot. Engr., Vol.4, No.2, pp.53-66, 1992.

4. Evers, E. and Waterhouse, A., "A Complete Model for Analyzing Smoke Movement in Buildings", Building Research Establishment, BRE CP 69/78.

5. Klote, J.H. and Milke, J.A., Design of Smoke Management Systems, p.46, 1992.

6. Tamura, G. T. and Shaw, C. Y., "Air Leakage Data For the Design .of Elevator and Stair Shaft Pressurization System", ASHRAE Transaction, Vol. 82, Part 2, pp.179-190, 1976.

7. Howard W. Emmons, "Vent Flows", The SFPE Handbook of FIRE PROTECTION ENGINEERING, First Edition, pp.1.132-134, 1990. 